ORIGINAL ARTICLE

\title{
Mortality of employees of the United Kingdom Atomic Energy Authority, 1946-97
}

\author{
W D Atkinson, D V Law, K J Bromley, H M Inskip
}

Occup Environ Med 2004;61:577-585. doi: 10.1136/oem.2003.012443

See end of article for authors' affiliations .....................

Correspondence to: Dr W Atkinson, Radiation Dosimetry, Health Physics Division, RWE NUKEM, 351.28 Harwell, Didcot OXI 1 ORA, UK; will.atkinson@ rwenukem.co.uk

Accepted 13 January 2004

\begin{abstract}
Background: The workforce of the UK Atomic Energy Authority has been the subject of several previous epidemiological investigations.

Aims: To detect and investigate associations between mortality rates and employment in a substantially increased cohort size and follow up extended to 1997.

Methods and Results: The new cohort included 51367 employees, of whom 10249 were dead. Mortality rates for all workers were low compared to national rates, as were rates in radiation workers and for workers monitored for internal contamination. For radiation workers all cause mortality and all cancer mortality were significantly lower than for non-radiation workers. There was no overall trend of increasing mortality with radiation dose. There was little evidence of raised mortality from leukaemia. The association of prostatic cancer with radiation dose was much less significant than in previous reports. However, the relatively high mortality from uterine cancers among radiation workers remained, though the numbers were very small. The association was with endometrial rather than cervical cancer. Mortality from cancer of the pleura was high among radiation workers, but was not correlated with dose.

Conclusion: Overall, radiation workers at UKAEA showed no excess mortality. The previously detected association of prostate cancer with high radiation dose may have been a statistical artefact or a risk associated with discontinued activities. Endometrial cancer occurred at higher rates in female radiation workers, but, because there was no correlation with dose, may well be due to something other than their radiation exposure. Cancer of the pleura in radiation workers was almost certainly related to past asbestos exposure.
\end{abstract}

E pidemiological studies of the health effects of ionising radiation are important in order that populations exposed to natural sources of radiation and workers and members of the public exposed to man-made sources should be protected from its harmful effects.

Early studies, starting with the ongoing cohort study on the Japanese bomb survivors, ${ }^{1}$ focused on acute exposures to high doses of radiation. However, it may not be possible to extrapolate directly from the effects of acute doses to those of the protracted exposures which are the usual way in which ionising radiation is encountered. ${ }^{2}$ That is why, in recent years, there has been increasing interest in studies of workers in the nuclear industry who may receive their doses over a working lifetime.

The first studies in the nuclear industry were relatively small and analysed cohorts from single employers or establishments. ${ }^{3-7}$ However, in recent years there has been an increasing tendency to focus on pooled studies involving national and international cohorts. ${ }^{8-11}$ This is important if the aim is to gain enough statistical power to make general statements about radiation risk and appropriate statutory radiation dose limits. However, some health effects show up in detailed studies of one workforce, but are swamped when pooled with information from other cohorts in which the baseline risks are quite different and in which different methods have been used to calculate exposures. An example is provided by studies of the United Kingdom Atomic Energy Authority (UKAEA) workforce in which prostate ${ }^{5}$ and uterine cancer ${ }^{13}$ have been identified as being associated with radiation work, but have done so only intermittently in other cohorts. There is, therefore, a question of whether these significant associations were the chance results that would be expected when many statistical tests were performed, or perhaps were associated with a hazard unique to radiation work in the UKAEA.

This paper presents a further analysis of the UKAEA cohort. The cohort has been increased by some 30\% to 51367 employees. Follow up has been extended to 1997, with 10249 deaths, which is about twice as many as in the previous analysis. With this significant extra power, the investigation considers overall mortality in the full workforce in relation to the general population of England and Wales and compares radiation workers to non-radiation workers. Previously reported raised mortality rates for prostate and uterine cancer were investigated with greater statistical confidence. Finally, the new cohort uniquely provides 50 years of data on the workforce of one nuclear industry employer, so the changing temporal pattern of mortality was analysed.

\section{METHODS}

Previous reports of the UKAEA mortality study describe its design and the methods of data collection and validation, ${ }^{5}$ so only an outline will be provided here.

\section{Study population}

The study population for previous analyses of the UKAEA workforce consisted of all employees who had ever worked at the Culham, Dounreay, Harwell, London, or Winfrith establishments between 1 January 1946 and 31 December 1979. Since then new recruits have been regularly added to the database and full data on them collected, including follow up information. The present study population includes all workers who had been employed before 31 March 1996.

Data from Risley and Culcheth establishments have also been included, but, because of gaps in the data, only for 


\section{Main messages}

- In the United Kingdom Atomic Energy Authority mortality rates from all causes and all cancers are significantly lower than in the general population of England and Wales.

- Overall mortality and mortality from all cancers among radiation workers is the same or less than in nonradiation workers.

- An association of prostate cancer with radiation work previously detected in this cohort may have been a statistical artefact or a risk associated with activities that are no longer carried out in UKAEA.

- Endometrial cancer continues to occur at a relatively high rate in female radiation workers, but may well be due to something other than their radiation exposure.

- Cancer of the pleura in radiation workers is almost certainly related to past asbestos exposure.

employees recruited after l January 1965. In order to eliminate survival bias, any workers employed at Risley or Culcheth before that date were excluded from the study population.

\section{Follow up}

Details of all members of the study population were sent to the National Health Service Central Registers (NHSCRs) at the Office for National Statistics in Southport and at the General Records Office (Scotland) in Edinburgh. Vital status was obtained and living members flagged for future notification if they died or emigrated. Cause of death was taken from the underlying cause on the death notification coded to the 9th revision of the International Classification of Diseases (ICD). The last date of follow up was taken as 31 December 1997.

An independent check on death notification by the NHSCRs was facilitated by the UKAEA Pensions Administration Office, which provided copies of the death certificate when a pensioner died. Further validation used the Department of Social Security Mortality Study Service (DSS) to check employees who were untraced by the NHSCRs and over- 85 year old cohort members whose deaths had not been notified to us by the NHSCRs. As a result of these checks the NHSCRs provided details of a further 67 deaths.

\section{Radiation exposure data}

Both radiation and non-radiation workers are included in the cohort. A radiation worker is an employee who has been issued routinely with a dosemeter and for whom a dose record has been maintained to demonstrate compliance with radiological protection regulations designed to make the workplace safe. Radiation workers have carried out a wide variety of industrial, scientific, and laboratory jobs within UKAEA as well as including other workers such as cleaners who have to enter areas where there is potential for radiation exposure. Many other UKAEA jobs have entailed no significant occupational exposure to radiation. They include, for example, clerical staff, caterers, scientists, and designers. Staff at all grades work as radiation and non-radiation workers, so the non-radiation workers provide a valuable control population for some analyses.

As in the previous UKAEA studies adjustments have been applied to the recorded radiation doses in order to standardise exposure data for unit changes, sub-threshold doses, and non-returned dosemeters. ${ }^{8}$ Only external whole body

\section{Policy implications}

- Judging by overall mortality rates, current standards of radiological safety seem to provide adequate protection for this nuclear industry cohort.

- Raised incidences of a single disease may be a chance finding and this should be considered before elaborate occupational health measures are put in place.

radiation dose was considered quantitatively here, although records of internal monitoring were used to classify workers as internally monitored or not. Dose from neutrons and intakes of tritium have been included in the external dose where this was part of the record keeping practices of the time. $^{8}$

Occupational doses incurred to the end of 1995 were considered for this analysis. Records of occupational exposure received before UKAEA employment were included because the information was available as transfer doses, but dose received after the last period of UKAEA employment was not generally available to the study.

\section{Data analysis}

All analyses of mortality were conducted using International Classification of Diseases (ICD) revision 9 cause codes. Where only earlier revisions were available from the NHSCRs and in the national data, they were converted to the nearest equivalent revision 9 code.

Person years at risk were calculated for each cohort member starting on their first day of employment or 1 January 1946, whichever was the later, and finishing on their death, emigration, or 31 December 1997, whichever was the earlier.

Person-years at risk and deaths were stratified by age (in five year age bands starting from 15-19 and ending with $85+$ ), sex, calendar year, social class (in six groups according to the British Registrar General's classification: I, II, III nonmanual, III manual, IV, V), employment establishment, and by cumulative radiation exposure (in five categories chosen for consistency with previous studies of the UKAEA workforce: $<10 \mathrm{mSv}, 10-<20 \mathrm{mSv}, 20-<50 \mathrm{mSv}, 50-<100 \mathrm{mSv}$, $\geqslant 100 \mathrm{mSv}$ ). In some analyses the doses were lagged by 10 years for solid cancers and 2 years for leukaemia to take account of the latent period. ${ }^{16}$

In the last study of the UKAEA workforce, ${ }^{13}$ uterine cancer was analysed as one disease category, although the aetiology of cervical cancer is quite different from cancer of the body of the uterus (endometrial cancer). ${ }^{15}{ }^{18}$ Since that study found some significant associations with radiation work, the components of uterine cancer were analysed separately in this study. Uterine cancers with site not specified (ICD code 179) were grouped with the endometrial cancers ${ }^{15}$ (ICD code 182) and cervical cancer (ICD code 180) was taken alone. Some cancers with very small numbers of deaths which were analysed previously were excluded this time.

Standardised mortality ratios (SMRs) were calculated comparing mortality rates in the UKAEA cohort with the mortality rates for England and Wales, stratified by age, sex, and calendar year. Ninety five per cent confidence intervals were calculated from the Poisson distribution, if possible, but where the number of deaths was large the normal approximation was used. ${ }^{16}$ National statistics for chronic lymphocytic leukaemia are not available prior to 1968, so SMRs for leukaemia excluding chronic lymphocytic leukaemia are calculated for the years 1968-97 only. 
Mortality rate ratios (RRs) comparing mortality in subjects with a radiation record with mortality in subjects without a radiation record were calculated using Poisson regression. Mortality rates and person-years were stratified by age, sex, calendar year, social class, and last UKAEA establishment. Where the number of deaths was less than 20, the $95 \%$ confidence interval was obtained using 10000 simulations.

Changing mortality with radiation dose was investigated using $\chi^{2}$ tests for trend. ${ }^{16}$ Mean doses in the dose bands for the particular cohort under investigation were used as the weights in the trend test. Two tailed tests were used to establish significant increases or decreases in mortality with dose. If the number of deaths in the disease under consideration was less than 20, significance was checked using 10000 simulations.

\section{RESULTS}

\section{Cohort description}

A total of 52356 workers qualified for the cohort on the basis of employment dates and establishment. Of these, 723 were not sent for flagging because of insufficient information and 266 were sent, but were untraced.

The final study population numbered 51 367, of whom $29 \%$ were women and $51 \%$ were radiation workers. The cohort was $30 \%$ larger than in previous studies; the number of deaths has nearly doubled to 10249 , of which 2956 were from cancer. Collective external radiation dose has increased from 862 man.Sv to 970 man.Sv. A total of 1856 were lost to follow up through emigration. Table 1 presents further characterisation of the cohort, including a breakdown into those who formed part of the original UKAEA cohort and new additions.

\section{All workers}

When the whole workforce was compared with the population of England and Wales, the standardised mortality ratio (SMR) was 78 (95\% CI 76.1 to 79.1) for all causes of death and 80 (95\% CI 77.3 to 83.1$)$ for all malignant neoplasms, both significantly less than 100 (table 2). The other broad categories of disease, ischaemic heart disease, and respiratory disease both had significantly lowered mortality rates. No cause of death had a significantly raised mortality rate compared to the population as a whole.

Table 1 Description of the whole UKAEA cohort with a breakdown into those individuals who were in the original mortality study and the new individuals who were recruited since 1979, or who were employed at Risley

\begin{tabular}{|c|c|c|c|}
\hline & $\begin{array}{l}\text { In original } \\
\text { cohort }\end{array}$ & $\begin{array}{l}\text { New } \\
\text { individuals }\end{array}$ & $\begin{array}{l}\text { Whole } \\
\text { cohort }\end{array}$ \\
\hline Total number of subjects & 37527 & 13840 & 51367 \\
\hline Dead on 31 Dec 1997 & 9828 & 421 & 10249 \\
\hline Deaths from cancer & 2776 & 180 & 2956 \\
\hline Deaths from other causes & 7052 & 241 & 7293 \\
\hline Not flagged for follow up & - & - & 989 \\
\hline Emigrated & 1657 & 199 & 1856 \\
\hline Women & 10267 & 4633 & 14900 \\
\hline Radiation workers & 21156 & 5239 & 26395 \\
\hline Mean year of birth & 1931 & 1955 & 1937 \\
\hline Mean age at hire & 29.9 & 26.5 & 29.0 \\
\hline $\begin{array}{l}\text { Mean duration of } \\
\text { employment }\end{array}$ & 10.8 & 7.7 & 10.0 \\
\hline Mean duration of follow up & 31.0 & 15.1 & 26.7 \\
\hline Total external dose (man.Sv) & 911.2 & 58.8 & 970 \\
\hline Mean annual dose (mSv) & 4.26 & 1.57 & 3.95 \\
\hline Mean cumulative dose (mSv) & 43.07 & 11.22 & 18.88 \\
\hline Person-years at risk & 1161799 & 209354 & 1371153 \\
\hline
\end{tabular}

Figure 1 shows how the SMR for all causes of death has changed over time, with a steady rise in the SMR over the 20 years from 1948 to 1968 followed by comparative stability since then.

A total of 1863 female members of the cohort had died by the time of the follow up, including 651 from malignant neoplasms (table 2). The SMR for all causes of death was 81 (95\% CI 76.9 to 84.3 ) and for all malignant neoplasms was 87 (95\% CI 80.5 to 94.1 ), values that were slightly higher than for the cohort as a whole. However, no SMRs were significantly raised and the SMR for cervical cancer was particularly low (SMR 55, 95\% CI 32 to 88). The only SMR that was markedly different from those in men was that for Hodgkin's disease in which the SMR in women was 187 (95\% CI 75 to 385) while the SMR in men was 47 (95\% CI 21 to 89).

\section{Radiation workers}

Table 3 presents SMRs for workers with a radiation record with comparable data for non-radiation workers. Table 4 presents rate ratios comparing mortality in radiation workers with non-radiation workers and tests for trend of mortality with radiation dose.

The SMR for all causes of death was 75 (95\% CI 73.5 to $77.5)$ and for all malignant neoplasms was 76 (95\% CI 72.2 to 79.8 ). For both groupings the mortality rate was significantly lower than for non-radiation workers.

Only 2390 of the female members of the cohort had a radiation record and there were 257 deaths among this group. The SMR for all causes of death was 72 (95\% CI 63.5 to 81.5 ) and for all malignant neoplasms was 79 (95\% CI 64.2 to $97.0)$. There was no association of all cause mortality with dose $\left(\chi_{1}^{2}=0.53, p=0.47\right)$, or of all cancer mortality $\left(\chi_{1}^{2}=1.36, p=0.24\right)$.

The one cause of death which showed a significantly raised mortality rate compared with national rates was endometrial cancer, which had an SMR of 386 (95\% CI 185 to 711) based on 10 deaths. The mortality rate relative to non-radiation workers was also significantly raised (RR 6.3, 95\% CI 2.2 to 20.0 ), but there was no suggestion that the risk was related to radiation dose $\left(\chi_{1}^{2}=0.08, p=0.78\right)$. Very similar results were obtained when the radiation exposure data was lagged by 10 years.

For cancer of the pleura there was a significantly raised risk in radiation workers relative to non-radiation workers, based on 10 deaths (RR 5.35, 95\% CI 1.36 to $\infty$ ), but again there was no trend with radiation dose $\left(\chi_{1}^{2}=0.36, p=0.55\right)$. Lagged radiation exposure made no difference to the results.

One of the most important findings of the first UKAEA mortality study was a highly significant trend of increasing risk of dying from prostate cancer with increasing radiation dose. This trend is very much weaker in the latest analysis $\left(\chi_{1}^{2}=2.32, p=0.13\right)$ and did not reach statistical significance. Neither the SMR among radiation workers of 84 (95\% CI 69.2 to 100.3 ), nor the rate ratio of 0.79 (95\% CI 0.59 to 1.06) give any evidence of a risk from radiation exposure.

For malignant melanoma mortality there was a positive trend with radiation dose which was close to statistical significance $\left(\chi_{1}^{2}=3.49, p=0.062\right)$. This was entirely accounted for by five deaths in the highest dose group. Overall, radiation workers had significantly lower mortality than non-radiation workers (RR $0.39,95 \%$ CI 0.17 to 0.87 ) for this disease.

The only other significant relation of mortality with radiation dose was for accidents, suicides, and violence in which there was a significant negative trend with dose $\left(\chi_{1}^{2}=4.9, p=0.03\right)$. There was also significantly lower mortality from this cause in radiation workers than in nonradiation workers. 


\begin{tabular}{|c|c|c|c|c|c|c|c|c|c|}
\hline \multirow[b]{2}{*}{$\begin{array}{l}\text { ICD code, } \\
\text { 9th revision }\end{array}$} & \multirow[b]{2}{*}{ Disease } & \multicolumn{4}{|c|}{ All workers } & \multicolumn{4}{|c|}{ All female workers } \\
\hline & & $\begin{array}{l}\text { Observed } \\
\text { deaths }\end{array}$ & $\begin{array}{l}\text { Expected } \\
\text { deaths }\end{array}$ & SMR & $95 \% \mathrm{Cl}$ & $\begin{array}{l}\text { Observed } \\
\text { deaths }\end{array}$ & $\begin{array}{l}\text { Expected } \\
\text { deaths }\end{array}$ & SMR & $95 \% \mathrm{Cl}$ \\
\hline $140-208$ & All malignant neoplasms & 2956 & 3689.7 & 80 & (77.3 to 83.1$)$ & 651 & 747.4 & 87 & (80.5 to 94.1 ) \\
\hline $140-149$ & Buccal cavity and pharynx & 36 & 52.8 & 68 & ( 47.7 to 94.3 ) & 6 & 7.4 & 81 & (29.8 to 177.4 ) \\
\hline 150 & Oesophagus & 104 & 129.1 & 81 & (65.9 to 97.7$)$ & 18 & 17.6 & 102 & (60.6 to 161.6$)$ \\
\hline 151 & Stomach & 221 & 287.3 & 77 & $(67.1$ to 87.8$)$ & 26 & 34.9 & 74 & (48.6 to 109.1 ) \\
\hline 153 & Large intestine & 238 & 253.3 & 94 & (82.4 to 106.7 ) & 53 & 58.0 & 91 & (68.5 to 119.6 ) \\
\hline 154 & Rectum & 106 & 154.6 & 69 & (56.2 to 83.0 ) & 12 & 25.1 & 48 & ( 24.7 to 83.6 ) \\
\hline $155-156$ & Liver and gall bladder & 45 & 57.1 & 79 & (57.5 to 105.5 ) & 10 & 11.4 & 88 & (42.1 to 161.6 ) \\
\hline 157 & Pancreas & 120 & 152.0 & 79 & (65.5 to 94.4 ) & 18 & 29.3 & 62 & (36.4 to 97.2 ) \\
\hline 161 & Larynx & 17 & 26.6 & 64 & (37.2 to 102.2 ) & 1 & 1.9 & 52 & $(0.7$ to 289.1$)$ \\
\hline 162 & Bronchus and lung & 820 & 1166.3 & 70 & $(65.6$ to 75.3$)$ & 105 & 114.0 & 92 & (75.4 to 111.5 ) \\
\hline 163 & Pleura & 11 & 14.6 & 76 & (37.7 to 135.3 ) & 0 & 0.9 & 0 & $(0.0$ to 0.0$)$ \\
\hline 172 & Malignant melanoma & 34 & 30.0 & 113 & (78.4 to 158.3 ) & 9 & 8.2 & 110 & (50.2 to 208.8 ) \\
\hline 174 & Breast & 162 & 176.7 & 92 & (78.1 to 106.9 ) & 160 & 175.6 & 91 & (77.6 to 106.4 ) \\
\hline $179-182$ & All uterus & 36 & 47.4 & 76 & (53.2 to 105.2 ) & 36 & 47.4 & 76 & (53.2 to 105.2 ) \\
\hline 180 & Cervix & 17 & 30.9 & 55 & $(32.0$ to 88.0 ) & 17 & 30.9 & 55 & (32.0 to 88.0 ) \\
\hline 179,182 & Endometrium & 19 & 16.4 & 116 & $(69.6$ to 180.6$)$ & 19 & 16.4 & 116 & $(69.6$ to 180.6$)$ \\
\hline $183^{102}$ & Ovary & 49 & 56.0 & 88 & (64.8 to 115.7 ) & 49 & 56.0 & 88 & (64.8 to 115.7 ) \\
\hline 185 & Prostate & 200 & 216.9 & 92 & $(79.9$ to 105.9$)$ & (2) & 0.0 & 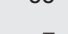 & (104.0 \\
\hline 186 & Testis & 14 & 9.8 & 142 & $(77.8$ to 239.0$)$ & & & & \\
\hline 188-189 & Urinary & 174 & 197.5 & 88 & (75.5 to 102.2$)$ & $1 \overline{3}$ & $2 \overline{2} .6$ & $5 \overline{8}$ & (30.6 to 98.4$)$ \\
\hline 189.0 & Kidney & 68 & 66.8 & 102 & $(79.0$ to 129.0$)$ & 7 & 9.7 & 72 & ( 28.8 to 148.3 ) \\
\hline $191-192$ & $\begin{array}{l}\text { Brain and other central nervous } \\
\text { system }\end{array}$ & 64 & 90.6 & 71 & (54.4 to 90.2 ) & 13 & 17.8 & 73 & (38.8 to 124.8 ) \\
\hline 193 & Thyroid & 11 & 7.2 & 152 & (75.8 to 272.1$)$ & 4 & 2.5 & 160 & (43.0 to 409.0 ) \\
\hline 195-199 & III defined and secondary & 188 & 226.6 & 83 & (71.5 to 95.7$)$ & 52 & 49.2 & 106 & (79.0 to 138.7$)$ \\
\hline $200-208$ & All lymphatic and haematopoietic & 240 & 245.8 & 98 & (85.7 to 110.8 ) & 52 & 47.7 & 109 & (81.3 to 142.8 ) \\
\hline 200,202 & Non-Hodgkin's lymphoma & 80 & 82.8 & 97 & (76.6 to 120.2 ) & 15 & 16.3 & 92 & (51.4 to 151.6 ) \\
\hline 201 & Hodgkin's disease & 16 & 22.9 & 70 & (39.9 to 113.5 ) & 7 & 3.7 & 187 & (75.0 to 385.7 ) \\
\hline 203 & Multiple myeloma & 41 & 46.5 & 88 & (63.3 to 119.7 ) & 8 & 9.6 & 84 & (36.0 to 164.8 ) \\
\hline 204-208 & Leukaemia & 103 & 93.6 & 110 & (89.8 to 133.5 ) & 22 & 18.1 & 121 & (76.1 to 183.9 ) \\
\hline $\begin{array}{l}204-208 \text { excl. } \\
204.1\end{array}$ & Leukaemia excl. CLL & 65 & 63.7 & 102 & (78.8 to 130.2 ) & 16 & 13.6 & 117 & (67.0 to 190.5 ) \\
\hline $410-414$ & Ischaemic heart disease & 3151 & 3860.0 & 82 & (78.8 to 84.5$)$ & 371 & 471.3 & 79 & (70.9 to 87.2$)$ \\
\hline $460-519$ & Respiratory disease & 980 & 1533.1 & 64 & $(60.0$ to 68.1$)$ & 167 & 234.4 & 71 & $(60.8$ to 82.9$)$ \\
\hline $800-999$ & Accidents, suicides, and violence & 501 & 568.0 & 88 & (80.7 to 96.3 ) & 70 & 80.2 & 87 & (67.6 to 109.6 ) \\
\hline 000-999 excl. & All causes except cancer & 7293 & 9521.2 & 77 & (74.9 to 78.4$)$ & 1212 & 1565.6 & 77 & $(73.1$ to 81.9$)$ \\
\hline 000-999 & All causes & 10249 & 13210.9 & 78 & (76.1 to 79.1$)$ & 1863 & 2313.0 & 81 & $(76.9$ to 84.3$)$ \\
\hline
\end{tabular}

\section{Workers monitored for internal contamination}

Table 3 presents SMRs for workers monitored for any form of internal contamination. Table 5 presents rate ratios comparing mortality in monitored workers with other radiation workers and tests for trend of mortality with external radiation dose.

Among workers monitored for any form of internal contamination the SMR for all cause mortality was 75 (95\% CI 71.7 to 78.7$)$ and for all malignant neoplasms was 78 (95\% CI 71.1 to 84.4 ). All cause mortality was significantly lower than for workers who only had external monitoring (RR 0.94,

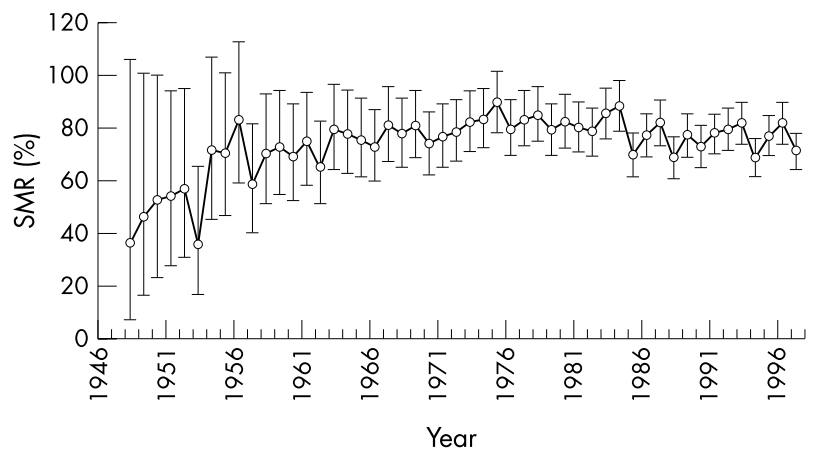

Figure 1 Variation with time in the SMR for all causes of death in the UKAEA cohort. Error bars indicate the $95 \% \mathrm{Cl}$.
$95 \%$ CI 0.88 to 0.99$)$. For prostate cancer, there was a trend of increasing mortality with external radiation dose in workers monitored for internal contamination that was close to statistical significance $\left(\chi_{1}^{2}=3.6, p=0.06\right)$ and also a higher than average SMR of 103 (95\% CI 76.5 to 136.7) and a rate ratio of 1.4 (95\% CI 0.95 to 2.04 ) compared to other radiation workers. However, the raised mortality was confined to the period 1946-79 (table 5).

There were only 18 deaths among female workers who had been monitored for internal contamination. The SMR for all causes was 54 (95\% CI 32.2 to 85.9) and the rate ratio for comparison with other female radiation workers was 0.64 (95\% CI 0.38 to 1.11 ). Among monitored women there was a significant trend of increasing mortality from all causes of death with radiation dose (positive trend $\chi_{1}^{2}=6.32$, $\mathrm{p}=0.012)$, although this was much weaker when the monitoring data were lagged by 10 years $\left(\chi_{1}^{2}=2.38\right.$, $\mathrm{p}=0.12)$. The SMR for endometrial cancer was $1183(95 \%$ CI 237.8 to 3457.7) and the rate ratio for comparison with other radiation workers was 12.96 (95\% CI 1.65 to $\infty)$, although based on only three deaths.

For plutonium workers the SMR for all causes was 81 (95\% CI 75.4 to 85.9 ) and for all cancers was 78 (95\% CI 68.5 to 87.9). There was a significantly high SMR for cancers of the uterus (SMR 669, 95\% CI 134 to 1955), especially for endometrial cancer (SMR 1538, 95\% CI 173 to 5555), although these are based on only three and two deaths respectively. The mortality rate for endometrial cancer was 


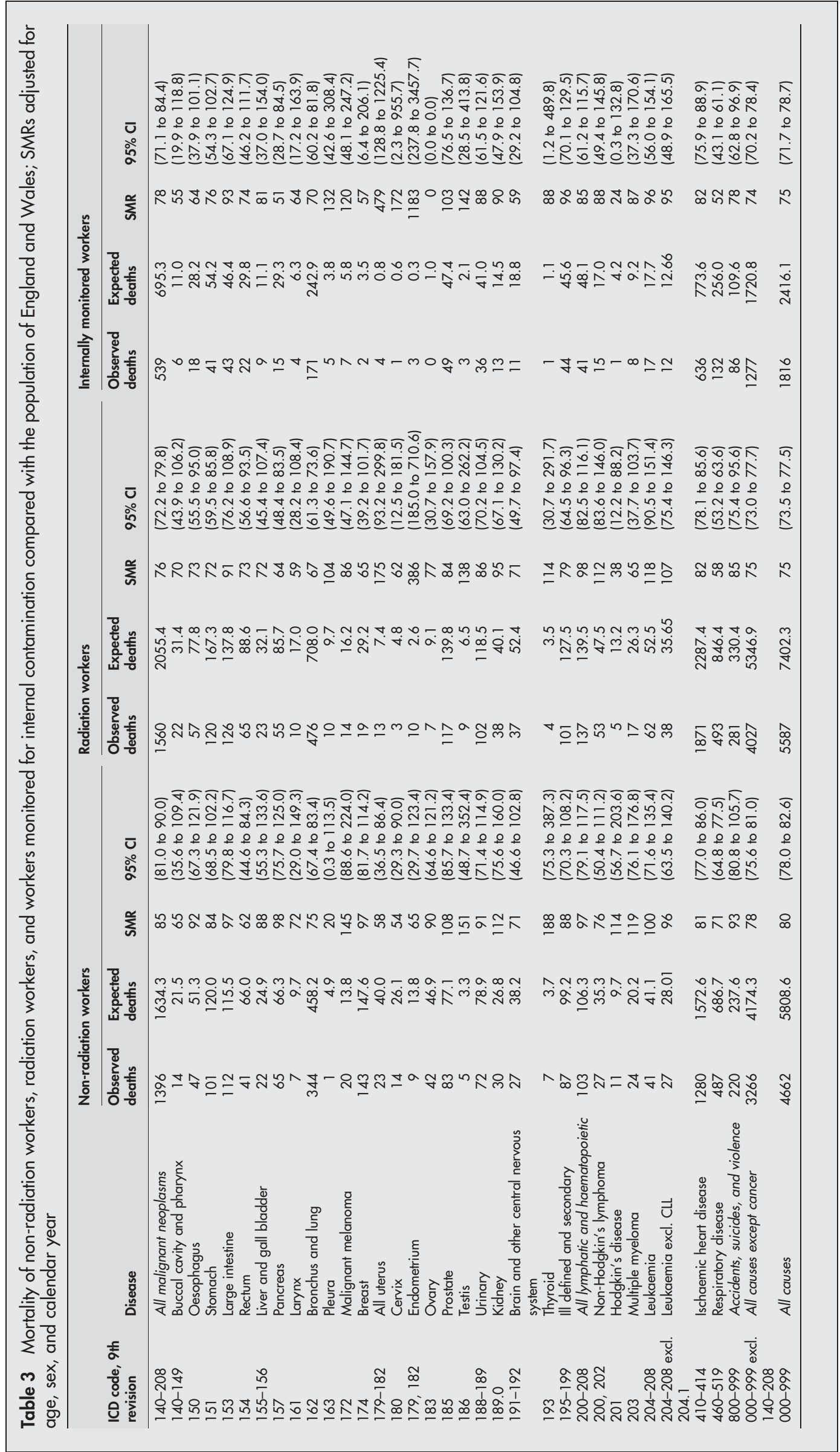




\begin{tabular}{|c|c|c|c|c|c|c|c|c|c|c|}
\hline \multirow{3}{*}{$\begin{array}{l}\text { ICD code, } \\
\text { 9th revision }\end{array}$} & \multirow[b]{3}{*}{ Disease } & \multirow[b]{3}{*}{ RR } & \multirow[b]{3}{*}{$95 \% \mathrm{Cl}$} & \multicolumn{7}{|l|}{ Dose trend } \\
\hline & & & & \multicolumn{5}{|c|}{ Observed/expected deaths } & \multirow{2}{*}{$\begin{array}{l}\chi_{1}^{2} \\
\text { (direction } \\
\text { of trend) }\end{array}$} & \multirow[b]{2}{*}{ p } \\
\hline & & & & $<10 \mathrm{mSv}$ & $10-<20 \mathrm{mSv}$ & $20-<50 \mathrm{mSv}$ & $50-<100 \mathrm{mSv}$ & $v 100+m S v$ & & \\
\hline $140-208$ & $\begin{array}{l}\text { All malignant } \\
\text { neoplasms }\end{array}$ & 0.92 & $(0.84$ to 1.00$)$ & $291 / 299$ & $245 / 250$ & $343 / 329$ & $189 / 175$ & $201 / 206$ & $0.0(+)$ & 1.00 \\
\hline $140-149$ & $\begin{array}{l}\text { Buccal cavity and } \\
\text { pharynx }\end{array}$ & 1.04 & (0.48 to 2.25$)$ & $10 / 8.7$ & $3 / 3.7$ & $2 / 4.3$ & $3 / 2.1$ & $4 / 3.2$ & $0.2(+)$ & 0.65 \\
\hline 150 & Oesophagus & 0.77 & (0.50 to 1.21$)$ & $23 / 20.8$ & $11 / 8.4$ & $10 / 10.7$ & $7 / 7.7$ & $6 / 9.4$ & $1.5(-)$ & 0.22 \\
\hline 151 & Stomach & 0.81 & $(0.60$ to 1.09 ) & $47 / 45.1$ & $19 / 19.0$ & $26 / 25.9$ & $9 / 13.3$ & $19 / 16.7$ & $0.1(+)$ & 0.79 \\
\hline 153 & Large intestine & 0.96 & $(0.71$ to 1.28$)$ & $46 / 45.7$ & $23 / 21.3$ & $29 / 27.6$ & $16 / 15.5$ & $12 / 15.9$ & $0.8(-)$ & 0.36 \\
\hline 154 & Rectum & 1.05 & $(0.67$ to 1.65$)$ & $25 / 24.5$ & $9 / 10.9$ & $20 / 14.1$ & $5 / 7.0$ & $6 / 8.5$ & $0.7(-)$ & 0.39 \\
\hline $155-156$ & $\begin{array}{l}\text { Liver and gall } \\
\text { bladder }\end{array}$ & 0.91 & $(0.46$ to 1.80$)$ & $9 / 8.9$ & $3 / 4.1$ & $10 / 4.7$ & $1 / 2.7$ & $0 / 2.6$ & $2.5(-)$ & 0.12 \\
\hline 157 & Pancreas & 0.60 & $(0.40$ to 0.89$)$ & $22 / 21.0$ & $11 / 8.4$ & $12 / 11.7$ & $7 / 6.3$ & $3 / 7.5$ & $2.4(-)$ & 0.12 \\
\hline 161 & Larynx & 0.83 & (0.29 to 2.38$)$ & $5 / 3.3$ & $0 / 1.4$ & $1 / 2.2$ & $2 / 1.4$ & $2 / 1.6$ & $0.1(+1$ & 0.78 \\
\hline 162 & Bronchus and lung & 0.98 & (0.84 to 1.15 ) & $173 / 181$ & $67 / 75$ & $107 / 102$ & $67 / 53$ & $62 / 64$ & $0.1(+)$ & 0.79 \\
\hline 163 & Pleura & 5.35 & $(1.36$ to $\infty)$ & $2 / 3.4$ & $2 / 1.8$ & $3 / 2.2$ & $3 / 1.5$ & $0 / 1.2$ & $0.4(-)$ & 0.55 \\
\hline 172 & $\begin{array}{l}\text { Malignant } \\
\text { melanoma }\end{array}$ & 0.39 & $(0.17$ to 0.87$)$ & $5 / 6.2$ & $2 / 2.0$ & $1 / 2.2$ & $1 / 1.5$ & $5 / 2.1$ & $3.5(+1)$ & 0.06 \\
\hline 174 & Breast & 0.64 & (0.39 to 1.07 ) & $13 / 13.8$ & $4 / 2.8$ & $1 / 1.5$ & $0 / 0.5$ & $1 / 0.4$ & $0.5(+)$ & 0.46 \\
\hline 179-182 & All uterus & 3.67 & (1.73 to 7.80$)$ & $9 / 8.5$ & $1 / 1.8$ & $1 / 2.4$ & $2 / 0.3$ & $0 / 0.04$ & $0.8(+)$ & 0.36 \\
\hline 180 & Cervix & 1.64 & (0.00 to 4.89 ) & $2 / 2.4$ & $0 / 0.3$ & $0 / 0.2$ & $1 / 0.1$ & $0 / 0.03$ & $1.1(+)$ & 0.30 \\
\hline \multirow[t]{3}{*}{179,182} & $\begin{array}{l}\text { Endometrium, all } \\
\text { years }\end{array}$ & 6.33 & (2.15 to 19.59 ) & $7 / 6.1$ & $1 / 1.6$ & $1 / 2.2$ & $1 / 0.2$ & $0 / 0.02$ & $0.1(+)$ & 0.78 \\
\hline & $\begin{array}{l}\text { Endometrium, } \\
1946-86\end{array}$ & 5.97 & (1.59 to 24.85$)$ & $4 / 3.2$ & $0 / 0.9$ & $1 / 1.9$ & $1 / 0.9$ & $0 / 0$ & $0.9(+)$ & 0.36 \\
\hline & $\begin{array}{l}\text { Endometrium, } \\
1987-97\end{array}$ & 6.98 & (1.47 to 36.07$)$ & $3 / 3.0$ & $1 / 0.7$ & $0 / 0.3$ & $0 / 0.06$ & $0 / 0.02$ & $0.13(-)$ & 0.72 \\
\hline 183 & Ovary & 0.65 & $(0.28$ to 1.55$)$ & $5 / 5.6$ & $0 / 0.9$ & $2 / 0.4$ & $0 / 0.06$ & $0 / 0.1$ & $0.0(+)$ & 0.86 \\
\hline \multirow{3}{*}{185} & Prostate, all years & 0.79 & $(0.59$ to 1.06$)$ & $33 / 40.9$ & $17 / 19.0$ & $30 / 27.1$ & $17 / 14.8$ & $20 / 15.2$ & $2.3(+)$ & 0.13 \\
\hline & Prostate, $1946-79$ & 1.16 & $(0.61$ to 2.22$)$ & $7 / 10.5$ & $3 / 4.6$ & $3 / 6.9$ & $6 / 2.8$ & $8 / 2.2$ & $17.5(+)$ & 0.00 \\
\hline & Prostate, $1980-97$ & 0.71 & $(0.50$ to 0.99$)$ & $26 / 30.5$ & $14 / 14.4$ & $27 / 20.2$ & $11 / 11.9$ & $12 / 13.0$ & $0.0(-1)$ & 0.92 \\
\hline 186 & Testis & 0.82 & $(0.31$ to 2.98$)$ & $4 / 4.4$ & $1 / 1.8$ & $3 / 1.8$ & $0 / 0.7$ & $1 / 0.5$ & $0.5(+)$ & 0.50 \\
\hline 188-189 & Urinary & 0.94 & $(0.67$ to 1.31$)$ & $41 / 37.4$ & $18 / 17.5$ & $16 / 21.8$ & $11 / 11.5$ & $16 / 13.8$ & $0.1(+)$ & 0.72 \\
\hline 189.0 & Kidney & 0.79 & (0.47 to 1.34 ) & $17 / 14.7$ & $8 / 6.4$ & $6 / 7.7$ & $5 / 4.4$ & $2 / 4.8$ & $1.7(-)$ & 0.19 \\
\hline $191-192$ & $\begin{array}{l}\text { Brain and other } \\
\text { central nervous } \\
\text { system }\end{array}$ & 1.00 & $(0.57$ to 1.77$)$ & $15 / 14.4$ & $8 / 6.2$ & $7 / 7.7$ & $3 / 4.3$ & $4 / 4.4$ & $0.2(-1)$ & 0.69 \\
\hline 193 & Thyroid & 0.83 & $(0.18$ to 3.28$)$ & $0 / 1.6$ & $0 / 0.3$ & $2 / 0.8$ & $1 / 0.5$ & $1 / 0.9$ & $0.2(+)$ & 0.65 \\
\hline 195-199 & $\begin{array}{l}\text { III defined and } \\
\text { secondary }\end{array}$ & 1.09 & $(0.78$ to 1.54 ) & $30 / 39.1$ & $15 / 15.3$ & $30 / 20.9$ & $10 / 11.9$ & $16 / 13.8$ & $0.6(+)$ & 0.44 \\
\hline $200-208$ & $\begin{array}{l}\text { All lymphatic and } \\
\text { haematopoietic }\end{array}$ & 1.03 & ( 0.76 to 1.40 ) & $52 / 50.2$ & $24 / 22.3$ & $23 / 29.8$ & $19 / 15.8$ & $19 / 18.9$ & $0.0(+)$ & 1.00 \\
\hline 200,202 & $\begin{array}{l}\text { Non-Hodgkin's } \\
\text { lymphoma }\end{array}$ & 1.72 & (0.98 to 3.02 ) & $23 / 20.2$ & $11 / 8.8$ & $6 / 10.9$ & $6 / 5.7$ & $7 / 7.4$ & $0.1(-)$ & 0.74 \\
\hline 201 & Hodgkin's disease & 0.46 & (0.10 to 1.57$)$ & $2 / 2.4$ & $1 / 0.8$ & $1 / 0.9$ & $1 / 0.3$ & $0 / 0.7$ & $0.3(-)$ & 0.59 \\
\hline 203 & Multiple myeloma & 0.42 & $(0.21$ to 0.85 ) & $7 / 5.2$ & $3 / 2.6$ & $2 / 3.8$ & $3 / 2.5$ & $2 / 2.9$ & $0.31-1$ & 0.57 \\
\hline $204-208$ & Leukaemia & 1.16 & $(0.72$ to 1.86$)$ & $20 / 22.3$ & $9 / 10.2$ & $14 / 14.3$ & $9 / 7.2$ & $10 / 8.0$ & $0.8(+)$ & 0.37 \\
\hline $\begin{array}{l}204-208 \text { excl } \\
204.1\end{array}$ & I. Leukaemia excl. CLL & 1.39 & (0.81 to 2.39 ) & $19 / 18.5$ & $5 / 8.1$ & $10 / 9.5$ & $5 / 5.2$ & $8 / 5.7$ & $0.9(+)$ & 0.35 \\
\hline $410-414$ & $\begin{array}{l}\text { Ischaemic heart } \\
\text { disease }\end{array}$ & 0.99 & (0.91 to 1.07 ) & $723 / 687$ & $273 / 292$ & $423 / 407$ & $197 / 215$ & $255 / 270$ & $1.5(-)$ & 0.21 \\
\hline $460-519$ & Respiratory disease & 0.81 & $(0.70$ to 0.94$)$ & $181 / 188$ & $72 / 80$ & $134 / 112$ & $48 / 53$ & $58 / 60$ & $0.0(-)$ & 0.89 \\
\hline $800-999$ & $\begin{array}{l}\text { Accidents, suicides, } \\
\text { and violence }\end{array}$ & 0.81 & $(0.67$ to 0.99 ) & $140 / 124$ & $49 / 47$ & $53 / 55$ & $20 / 27$ & $19 / 28$ & $4.9(-)$ & 0.03 \\
\hline 000-999 & All causes & 0.93 & $(0.89$ to 0.97$)$ & $2149 / 2122$ & $857 / 894$ & $1246 / 1195$ & $607 / 616$ & $697 / 729$ & $1.3(-)$ & 0.25 \\
\hline
\end{tabular}

also significantly higher than for other radiation workers (RR 56.6, $95 \%$ CI 8.3 to $\infty$ ). There was no significant trend with dose, however (negative trend $\chi_{1}^{2}=1.61, p=0.20$ ).

Among plutonium monitored workers the SMR for cancer of the pleura was nearly significant (SMR 282, 95\% CI 91 to 659 ) and was significant when exposure was lagged by 10 years (SMR 329, 95\% CI 106 to 768). The mortality rate was significantly higher than for other radiation workers (RR 6.7, $95 \%$ CI 1.5 to 28.5 ), but there was no significant trend with dose (negative trend $\chi_{1}^{2}=0.37, \mathrm{p}=0.54$ ).

Among tritium monitored workers no SMRs were significantly raised and some were particularly low. The SMR for all causes of death was only 69 (95\% CI 61.9 to 76.0$)$ and for all cancers was 71 (95\% CI 58.5 to 85.1$)$. One rate ratio is significantly raised in this group of workers, that for prostate cancer (RR 1.8, 95\% CI 1.0 to 3.1), but the trend with dose was not significant (positive trend $\chi_{1}^{2}=0.36, p=0.55$ ). The rate ratio was particularly high for the time period up to and including 1979 (RR 5.8, 95\% CI 2.2 to 15.7), but not for the years post-1979 (RR 1.2 , 95\% CI 0.6 to 2.4 ).

\section{DISCUSSION}

\section{All causes of death}

As in previous studies of the UKAEA workforce and of other workers in the nuclear industry, overall mortality is low compared to the general population. SMRs are generally between 75 and 80 for most sub-cohorts. The changes in SMR with time (fig 1) show that it is likely that the low SMRs in the UKAEA can, at least partly, be explained by the recruitment of healthy workers. When, in the early years, 


\begin{tabular}{|c|c|c|c|c|c|c|c|c|c|c|}
\hline \multirow{3}{*}{$\begin{array}{l}\text { ICD code, } \\
\text { 9th revision }\end{array}$} & \multirow[b]{3}{*}{ Disease } & \multirow[b]{3}{*}{ RR } & \multirow[b]{3}{*}{$95 \% \mathrm{Cl}$} & \multicolumn{7}{|l|}{ Dose trend } \\
\hline & & & & \multicolumn{5}{|c|}{ Observed/expected deaths } & \multirow{2}{*}{$\begin{array}{l}\chi_{1}^{2} \text { (direction } \\
\text { of trend) }\end{array}$} & \multirow{2}{*}{$p$} \\
\hline & & & & $<10 \mathrm{mSv}$ & $10-<20 \mathrm{mSv}$ & $20-<50 \mathrm{mSv}$ & $50-<100 \mathrm{mSv}$ & $100+\mathrm{mSv}$ & & \\
\hline $140-208$ & $\begin{array}{l}\text { All malignant } \\
\text { neoplasms }\end{array}$ & 1.01 & $(0.90-1.13)$ & $59 / 67.9$ & $58 / 58.3$ & $150 / 136.5$ & $105 / 109.8$ & $167 / 166.5$ & $0.0(+)$ & 1.00 \\
\hline $140-149$ & $\begin{array}{l}\text { Buccal cavity and } \\
\text { pharynx }\end{array}$ & 0.67 & $(0.24-1.86)$ & $0 / 0.8$ & $1 / 0.7$ & $0 / 1.7$ & $2 / 0.9$ & $3 / 1.9$ & $1.0(+)$ & 0.32 \\
\hline 150 & Oesophagus & 0.65 & $(0.36-1.18)$ & $0 / 1.9$ & $3 / 2.3$ & $5 / 3.9$ & $4 / 4.1$ & $6 / 6.0$ & $0.0(+)$ & 0.92 \\
\hline 151 & Stomach & 1.01 & $(0.67-1.51)$ & $6 / 4.8$ & $5 / 4.4$ & $12 / 10.7$ & $5 / 8.1$ & $13 / 13.0$ & $0.1(-)$ & 0.82 \\
\hline 153 & Large intestine & 1.02 & $(0.69-1.50)$ & $3 / 5.0$ & $6 / 5.8$ & $14 / 10.3$ & $10 / 9.3$ & $10 / 12.5$ & $0.3(-)$ & 0.58 \\
\hline 154 & Rectum & 1.04 & $(0.60-1.82)$ & $2 / 2.4$ & $2 / 1.8$ & $10 / 6.6$ & $3 / 4.8$ & $5 / 6.4$ & $0.4(-)$ & 0.52 \\
\hline $155-156$ & $\begin{array}{l}\text { Liver and gall } \\
\text { bladder }\end{array}$ & 1.14 & $(0.47-2.77)$ & $3 / 1.9$ & $1 / 1.3$ & $4 / 2.2$ & $1 / 1.6$ & $0 / 2.0$ & $2.2(-)$ & 0.14 \\
\hline 157 & Pancreas & 0.70 & $(0.38-1.32)$ & $1 / 1.6$ & $3 / 1.7$ & $6 / 3.9$ & $3 / 3.0$ & $2 / 4.8$ & $1.4(-)$ & 0.23 \\
\hline 161 & Larynx & 1.17 & $(0.14-6.35)$ & $0 / 0.6$ & $0 / 0.3$ & $1 / 0.8$ & $1 / 0.9$ & $2 / 1.4$ & $0.3(+)$ & 0.59 \\
\hline 162 & Bronchus and lung & 1.04 & $(0.85-1.27)$ & $24 / 20.9$ & $15 / 16.9$ & $45 / 41.3$ & $36 / 34.0$ & $51 / 57.8$ & $0.7(-)$ & 0.41 \\
\hline 163 & Pleura & 1.80 & $(0.43-\infty)$ & $0 / 0.4$ & $0 / 0.7$ & $2 / 1.1$ & $3 / 1.5$ & $0 / 1.3$ & $0.5(-)$ & 0.46 \\
\hline 172 & $\begin{array}{l}\text { Malignant } \\
\text { melanoma }\end{array}$ & 1.50 & $(0.56-4.06)$ & $0 / 0.8$ & $1 / 1.2$ & $1 / 1.7$ & $1 / 1.5$ & $4 / 1.7$ & $2.9(+)$ & 0.09 \\
\hline 174 & Breast & 0.73 & $(0.00-2.56)$ & $1 / 1$ & $0 / 0.5$ & $0 / 0.2$ & $0 / 0$ & $1 / 0.4$ & $1.9(+)$ & 0.17 \\
\hline $179-182$ & All uterus & 6.59 & $(1.40-43.60)$ & $2 / 2.54$ & $1 / 0.4$ & $0 / 0.9$ & $1 / 0.05$ & $0 / 0.12$ & $0.0(+)$ & 0.86 \\
\hline 180 & Cervix & 1.11 & $(0.00-\infty)$ & $0 / 1$ & $0 / 0$ & $0 / 0$ & $1 / 0$ & $0 / 0$ & $365.0(+)$ & 0.00 \\
\hline 179,182 & Endometrium & 12.96 & $(1.65-\infty)$ & $2 / 1.5$ & $1 / 0.4$ & $0 / 0.9$ & $0 / 0.05$ & $0 / 0.12$ & $0.4(-)$ & 0.51 \\
\hline 183 & Ovary & - & - & - & - & - & - & - & - & - \\
\hline \multirow[t]{2}{*}{185} & $\begin{array}{l}\text { Prostate, all years } \\
\text { Prostate, 1946-79 }\end{array}$ & $\begin{array}{l}1.39 \\
1.36\end{array}$ & $\begin{array}{l}(0.95-2.04) \\
(0.90-2.08)\end{array}$ & $\begin{array}{l}3 / 5.0 \\
0 / 1.09\end{array}$ & $\begin{array}{l}2 / 5.1 \\
0 / 1.29\end{array}$ & $\begin{array}{l}14 / 14.0 \\
2 / 3.6\end{array}$ & $\begin{array}{l}10 / 12.1 \\
1 / 1.9\end{array}$ & $\begin{array}{l}20 / 12.8 \\
8 / 3.1\end{array}$ & $\begin{array}{l}3.60(+) \\
7.0(+)\end{array}$ & $\begin{array}{l}0.06 \\
0.01\end{array}$ \\
\hline & Prostate, $1980-97$ & 0.75 & $(0.61-0.93)$ & $3 / 3.9$ & $2 / 3.8$ & $12 / 10.4$ & $9 / 10.2$ & $12 / 9.7$ & $0.5(+)$ & 0.49 \\
\hline 186 & Testis & 1.11 & $(0.25-5.19)$ & $0 / 0.6$ & $1 / 0.6$ & $1 / 1.1$ & $0 / 0.5$ & $1 / 0.3$ & $1.5(+)$ & 0.23 \\
\hline 188-189 & Urinary & 1.08 & $(0.70-1.65)$ & $2 / 4.4$ & $4 / 3.5$ & $10 / 8.8$ & $6 / 6.7$ & $14 / 12.7$ & $0.2(+)$ & 0.68 \\
\hline 189.0 & Kidney & 0.99 & $(0.49-1.97)$ & $1 / 1.2$ & $4 / 1.3$ & $5 / 3.7$ & $2 / 3.0$ & $1 / 3.9$ & $2.4(-)$ & 0.12 \\
\hline $191-192$ & $\begin{array}{l}\text { Brain and other } \\
\text { central nervous } \\
\text { system }\end{array}$ & 0.74 & (0.34-1.58) & $5 / 2.2$ & $1 / 1.2$ & $1 / 2.7$ & $1 / 2.4$ & $3 / 2.5$ & $0.0(+1$ & 1.00 \\
\hline 193 & Thyroid & 0.50 & $(0.00-\infty)$ & $0 / 0.05$ & $0 / 0.07$ & $0 / 0.3$ & $0 / 0.2$ & $1 / 0.4$ & $0.9(+)$ & 0.33 \\
\hline 195-199 & $\begin{array}{l}\text { III defined and } \\
\text { secondary }\end{array}$ & 1.53 & $(1.01-2.32)$ & $4 / 5.4$ & $4 / 4.8$ & $17 / 12.1$ & $6 / 8.4$ & $13 / 13.4$ & $0.0(-)$ & 0.89 \\
\hline $200-208$ & $\begin{array}{l}\text { All lymphatic and } \\
\text { haematopoietic }\end{array}$ & 0.74 & $(0.50-1.10)$ & $3 / 5.0$ & $7 / 4.76$ & $4 / 9.9$ & $11 / 8.5$ & $16 / 12.9$ & $0.9(+)$ & 0.34 \\
\hline 200,202 & $\begin{array}{l}\text { Non-Hodgkin's } \\
\text { lymphoma }\end{array}$ & 0.68 & $(0.36-1.27)$ & $1 / 1.7$ & $4 / 1.8$ & $0 / 3.9$ & $4 / 2.5$ & $6 / 5.0$ & $0.2(+)$ & 0.62 \\
\hline 201 & Hodgkin's disease & 0.54 & $(0.00-4.64)$ & $0 / 0.06$ & $0 / 0.03$ & $0 / 0.11$ & $1 / 0.11$ & $0 / 0.7$ & $0.4(-)$ & 0.54 \\
\hline 203 & Multiple myeloma & 1.20 & $(0.37-3.69)$ & $1 / 0.9$ & $1 / 0.5$ & $1 / 1.4$ & $3 / 2.4$ & $2 / 2.8$ & $0.2(-)$ & 0.70 \\
\hline $204-208$ & Leukaemia & 0.71 & $(0.39-1.28)$ & $1 / 2.3$ & $2 / 2.4$ & $3 / 4.5$ & $3 / 3.5$ & $8 / 4.5$ & $2.6(+)$ & 0.11 \\
\hline $\begin{array}{l}204-208 \\
\text { excl. } 204.1\end{array}$ & $\begin{array}{l}\text { Leukaemia excl. } \\
\text { CLL }\end{array}$ & 0.88 & $(0.45-1.72)$ & $1 / 2.0$ & $2 / 2.1$ & $3 / 3.9$ & $1 / 2.5$ & $7 / 3.4$ & $3.0(+1)$ & 0.08 \\
\hline $410-414$ & $\begin{array}{l}\text { Ischaemic heart } \\
\text { disease }\end{array}$ & 0.94 & $(0.85-1.05)$ & $80 / 70.4$ & $53 / 63.1$ & $154 / 153.6$ & $133 / 125.3$ & $216 / 223.7$ & $0.2(-)$ & 0.67 \\
\hline $460-519$ & Respiratory disease & 0.75 & $(0.60-0.92)$ & $15 / 15.6$ & $12 / 14.0$ & $44 / 34.1$ & $18 / 27.7$ & $43 / 40.7$ & $0.0(+)$ & 0.92 \\
\hline 800-999 & $\begin{array}{l}\text { Accidents, suicides, } \\
\text { and violence }\end{array}$ & 0.86 & $(0.67-1.12)$ & $27 / 21.1$ & $11 / 12.5$ & $20 / 19.1$ & $11 / 13.7$ & $17 / 19.6$ & $0.7(+)$ & 0.41 \\
\hline 000-999 & All causes & 0.94 & $(0.88-0.99)$ & $232 / 228$ & $180 / 193$ & $466 / 444$ & $355 / 358$ & $571 / 580$ & $0.1(-)$ & 0.72 \\
\hline
\end{tabular}

the workforce consisted largely of recent recruits, SMRs were exceptionally low. As the early recruits became established employees, the SMRs rose until an equilibrium between recruitment and retirement was reached when the SMR levelled out. In fact over the past 10 years SMRs seem to have declined somewhat. It is also likely that social class plays some part in the observed healthy worker effect. In the second analysis of the National Registry for Radiation Workers, ${ }^{9}$ some SMRs were adjusted for social class and were rather higher than the unadjusted values, though still significantly less than 100 .

There is some evidence of a difference between radiation workers and non-radiation workers in their overall mortality rates, with an overall rate ratio significantly less than 1 (table 4). The difference might be explained by the reduced opportunities for radiation workers to smoke at work. The very low rate ratio for respiratory diseases is consistent with this, but the rate ratios for lung cancer and ischaemic heart disease are not. Rates of respiratory disease are particularly affected by recruitment policy and a likely explanation of the low mortality rate in radiation workers is more stringent employment selection criteria applied to some in that group.

\section{Leukaemia}

Leukaemia (excluding chronic lymphocytic leukaemia) is the disease most often linked to radiation exposure, ${ }^{12}$ but in the UKAEA workforce there is little evidence of raised mortality from leukaemia associated with occupational exposure. Overall SMRs are around 100 (table 2). While these are higher SMRs than for most cancers, the fact that there is no significant excess in radiation workers and no significant trend of increasing mortality with radiation dose, suggests that other characteristics of the workforce, such as its relatively high social class composition (UKAEA has been primarily a research and development organisation), may account for the higher than average rates. 


\section{Uterine cancer}

In the last analysis of mortality in the UKAEA workforce, ${ }^{13}$ female radiation workers showed significantly higher mortality from uterine cancer than non-radiation workers. The mortality also showed a significant trend with radiation exposure, though the results were based on only eight deaths from uterine cancer in radiation workers. In that analysis, mortality from cervical cancer was not distinguished from endometerial cancer as it was in this.

As in the last analysis, mortality from uterine cancer was significantly higher among radiation workers than nonradiation workers (table 4 ). The excess was more or less confined to endometrial cancer in which the relative risk was 6.3 and highly significant, though based on only 10 deaths in radiation workers. There was a significant relative risk, both in the time period used in the last analysis (1946-86) and in the subsequent data (1987-97). The risk was even higher in women monitored for internal contamination, with a relative risk of nearly 13 compared to other radiation workers (table 5). Unlike in the previous analysis, there is no suggestion of a trend of increasing mortality with radiation dose.

Such a striking excess risk of mortality from uterine cancer has not been observed before in cohorts exposed to radiation, although most of those studies have included few women and they have rarely separated endometrial cancer from cervical cancer. The recent study of the Springfields uranium production facility ${ }^{17}$ does show an excess of uterine cancers compared to national rates, but the excess is found in both radiation and non-radiation workers. There is also information in this area from the Japanese bomb survivors among whom there were 382 deaths from all uterine cancers up to $1986,{ }^{1}$ of which only 90 were cervical cancer. For all uterine cancers the excess risk at 1 Gy was only 0.22 and was barely significant (the equivalent figure for leukaemia was 3.9). Uterine cancer has not, then, been shown to be particularly radiation sensitive.

Examination of the detailed career histories of all the women who died from endometrial cancer suggests no shared work experience which might have contributed to the disease.

One possible explanation for the excess mortality seen in the UKAEA radiation workers is that they differ from nonradiation workers in ways other than their radiation dose that are related to the aetiology of endometrial cancer. Parazzini and colleagues $^{18}$ have recently reviewed the epidemiology of endometrial cancer and have emphasised the role of oestrogens, particularly when associated with low progesterone levels. Predisposing factors include overweight, early menarche, late menopause, and nulliparity. However, any association of radiation work with these factors would be speculative because of a lack of data.

It is to be hoped that future studies of uterine cancer in radiation exposed cohorts will separate cervical cancer from endometrial cancer in order to cast more light on this problem.

\section{Prostate cancer}

Previous analyses of mortality in the UKAEA workforce have detected a significant association of mortality from prostate cancer with radiation dose and with monitoring for tritium. ${ }^{5}$ A case-control study ${ }^{12}$ narrowed down the association to work in environments potentially contaminated with five different radionuclides including tritium. Those environments tended to be found in heavy water reactors.

In this study the association of prostate cancer with radiation dose (table 4) was much less strong than before and was not statistically significant. This was because the trend was confined to the period up to and including 1979, that was covered by the first analysis of the UKAEA cohort. ${ }^{5}$ There was no trend at all of increasing prostate cancer mortality with radiation dose in the years following that observation (table 4). This is despite the fact that solid cancers have a long latent period and that heavy water reactors, the source of the putative hazard, continued in operation until 1990 at Harwell and 1991 at Winfrith. This would seem to increase the doubt that there is a radiological explanation for the previous prostate cancer excess. ${ }^{19}$

\section{Cancer of the pleura}

Among radiation workers and particularly among those monitored for plutonium exposure there was a significant excess mortality from cancer of the pleura, but with no evidence of a trend with radiation dose. Other recent studies of workers in the nuclear industry have reported similar findings. ${ }^{11} 20$ Almost all such cancers are mesotheliomas and are strongly related to exposure to asbestos. ${ }^{21}$ It seems likely that in the past, radiation workers, who are more likely than non-radiation workers to be involved with industrial work, were significantly exposed to asbestos in production facilities and other industrial buildings. Mesotheliomas have very long latent periods, so it is likely that this excess will become more apparent in the future.

\section{CONCLUSIONS}

In the UKAEA workforce no cause of death had a significantly raised mortality rate compared to the population of England and Wales as a whole. The overall standardised mortality ratio was 78 (95\% CI 76.1 to 79.1$)$ for all causes of death and 80 (95\% CI 77.3 to 83.1) for malignant neoplasms. For all radiation workers these figures were 75 (95\% CI 73.5 to 77.5$)$ and 76 (95\% CI 72.2 to 79.8 ) respectively.

In the last analysis of the UKAEA workforce ${ }^{13}$ the major concerns were prostate cancer and cancer of the uterus. The present report, with its increased power and extended time span has shown that there has been no association of mortality from prostate cancer with dose since the data which first gave rise to concern were collected. This is despite the fact that the heavy water reactors, which were implicated as risk factors, ${ }^{12}$ continued in operation for much of the later period. This must increase the probability that the original observation was a chance finding of the kind that can happen when multiple significance tests are carried out.

There remains a higher than average mortality rate for uterine cancer and specifically for endometrial cancer in the UKAEA workforce, although the absolute number of deaths is small. No association with radiation dose was evident and it is possible that this was a chance finding, or that some characteristic of female radiation workers other than their radiation exposure is the source of the risk.

\section{ACKNOWLEDGEMENTS}

We thank the team from the London School of Hygiene and Tropical Medicine and UKAEA who designed the study and carried out previous analyses of this cohort, especially Pat Fraser, Valerie Beral, Margaret Booth, Brian Wade, and Len Salmon. We acknowledge the support and advice of Adrian Foster and Robin Wood from UKAEA. The staff of the NHSCRs at Southport and Edinburgh, at the Contributions Agency of the Department of Social Security, and at the UKAEA Pensions Office were of great assistance in providing follow up information.

\section{Authors' affiliations}

W D Atkinson, D V Law, K J Bromley, Health Effects, RWE NUKEM, 351.28 Harwell, Didcot, Oxfordshire OX11 ORA, UK H M Inskip, MRC Environmental Epidemiology Unit, University of Southampton, Southampton General Hospital, Southampton SO16 6YD, UK 


\section{REFERENCES}

1 Pierce DA, Shimizu Y, Preston DL, et al. Studies of the mortality of atomic bomb survivors. Report 12, Part I. Cancer: 1950-1990. Radiat Res 1996; 146: 1-27.

2 National Research Council, Committee on the Biological Effects of lonizing Radiations. Health effects of exposure to low levels of ionizing radiation (BEIR V). Washington, DC: National Academy Press, 1990

3 Mancuso T, Stewart A, Kneale G. Radiation exposures of Hanford workers dying from cancer and other causes. Health Physics 1977;33:369-85.

4 Gilbert ES, Omohundro E, Buchanan JA, et al. Mortality of workers at the Hanford site: 1945-1986. Health Physics 1993;64:577-90.

5 Beral V, Inskip H, Fraser P, et al. Mortality of employees of the United Kingdom Atomic Energy Authority, 1946-1979. BM 1985;291:440-7.

6 Beral V, Fraser P, Carpenter L, et al. Mortality of employees of the Atomic Weapons Establishment, 1951-82. BMJ 1988;297:757-70.

7 Smith PG, Douglas AJ. Mortality of workers at the Sellafield plant of British Nuclear Fuels. BMJ 1986;293:845-54.

8 Carpenter L, Higgins C, Douglas A, et al. Combined analysis of mortality in three United Kingdom nuclear industry workforces, 1946-1988. Radiat Res 1994:138:224-38.

9 Muirhead CR, Goodill AA, Haylock RGE, et al. Occupational radiation exposure and mortality: second analysis of the National Registry for Radiation Workers. J Radiol Prot 1999;19:3-26.

10 Cardis E, Gilbert ES, Carpenter L, et al. Effects of low doses and low dose rates of external ionizing radiation: cancer mortality among nuclear industry workers in three countries. Radiat Res 1995; 142:117-32.
11 Gilbert ES, Cragle DL, Wiggs LD. Updated analyses of combined mortality data for workers at the Hanford site, Oak Ridge National Laboratory, and Rocky Flats Weapons Plant. Radiat Res 1993;136:408-21.

12 Rooney C, Beral V, Maconochie N, et al. Case-control study of prostatic cancer in employees of the United Kingdom Atomic Energy Authority. BMJ 1993;307:1391-7.

13 Fraser P, Carpenter L, Maconochie N, et al. Cancer mortality and morbidity in employees of the United Kingdom Atomic Energy Authority, 1946-86. $\mathrm{Br} J$ Cancer 1993;67:615-24.

14 Fraser $\mathbf{P}$, Booth $M$, Beral V, et al. Collection and validation of data in the United Kingdom Atomic Energy Authority mortality study. BMJ 1985;291:435-9.

15 Mant JWF, Vessey MP. Ovarian and endometrial cancers. Cancer surveys. Vol. 19: Trends in cancer incidence and mortality. Imperial Cancer Research Fund, 1994.

16 Breslow NE, Day NE. Statistical methods in cancer research, Vol. II. The design and analysis of cohort studies. Lyon: IARC, 1987.

17 McGeoghegan D, Binks K. The mortality and cancer morbidity experience of workers at the Springfields uranium production facility, 1946-95. J Radiol Prot 2000;20:111-37.

18 Parazzini F, Franceschi S, La Vecchia C, et al. The epidemiology of female genital tract cancers. Int J Gynecol Cancer 1997;7:169-81.

19 Atkinson WD, Bull RK, Marshall M, et al. The association between prostate cancer and exposure to ${ }^{65} \mathrm{Zn}$ in UKAEA employees. J Radiol Prot 1994; 14:109-14.

20 Omar RZ, Barber JA, Smith PG. Cancer mortality and morbidity among plutonium workers at the Sellafield plant of British Nuclear Fuels. Br J Cancer 1999:79:1288-301.

21 Higginson J, Muir CS, Muñoz N. Human cancer: epidemiology and environmental causes. Cambridge: Cambridge University Press, 1992.

Answers to multiple choice questions on Health promotion in the workplace by $M$ Shain and D M Kramer, on pages 643-648

(1) (d)

(2) (a) false; (b) false

(3) (b), (d), (e)

(4) (a) false; (b) false

(5) (e) 